\title{
In vivo tissue engineering an autologous semilunar biovalve: Can we get what we want?
}

Hans-Hinrich Sievers, MD

See related article on page 152

$\mathcal{B}$ Supplemental material is available online.
From the Department of Cardiac Surgery, University of Schleswig-Holstein, Campus Luebeck, Luebeck, Germany,

Received for publication March 12, 2007; revisions received March 21, 2007; accepted for publication March 29, 2007.

Address for reprints: Hans-Hinrich Sievers, MD, University of Schleswig-Holstein, Campus Luebeck, Department of Cardiac Surgery, Ratzeburger Allee 160, Luebeck D-23538 Germany (E-mail: herzchir@ medinf.mu-luebeck.de).

J Thorac Cardiovasc Surg 2007;134:20-2

$0022-5223 / \$ 32.00$

Copyright $\odot 2007$ by The American Association for Thoracic Surgery

doi:10.1016/j.jtcvs.2007.03.028
$\mathrm{S}$ ince the 1950s, conventional bioprosthetic and mechanical heart valve substitutes have significantly improved survival and quality of life for millions of patients. Nevertheless, these replacement devices are subject to serious, still unsurmounted, shortcomings, among others macroembolic and microembolic events, anticoagulation, premature degeneration and failure, functional imperfection, and lack of growth. Thus, there is an undoubted need for better prostheses. Tissue engineering has evolved during the last 20 years as an appealing alternative with great promise, bringing into play the application of principles and methods of engineering and life science. ${ }^{\mathrm{E} 1}$ Understandably, the ultimate goal is to construct a living aortic valve substitute equal to the patient's own native valve. This makes sense, because the native valve is the optimal solution as a valve mechanism for that particular position that has developed in an evolutionary process over millions of years, an inconceivable period for human beings. For tissue engineering, a thorough understanding of developmental processes, as well as of relationships of structure to function, is indispensable. Some issues are touched on in the present study with regard to semilunar heart valves.

The heart and the valves are the first organs to form during a complex morphogenetic process harmonizing with evolving hemodynamic forces. ${ }^{1}$ In addition to transition of endothelial to mesenchymal cells and migration of these cells to form the endocardial cushions, numerous genes, molecules, signals, and proteins are involved. ${ }^{\mathrm{E} 2, \mathrm{E} 3}$ Of most interest, multipotent neural crest cells migrate to the outflow tract $^{2}$ (Figure 1) and semilunar valves, ${ }^{\mathrm{E} 4, \mathrm{E} 5}$ contributing to development. ${ }^{\mathrm{E} 4}$ This process follows a finely tuned, albeit vulnerable, ${ }^{\text {E6-E8 }}$ biologic concert not yet completely known, which is also true for the molecular mechanisms to maintain structural integrity, regeneration, aging, and remodeling in response to dynamic environmental factors. ${ }^{3}$ How do cells differentiate at the right time, to the right extent, into the right type, and in the right position? What is the control mechanism? Is the neural system the major player during development?

Understanding of not only molecular mechanisms but also details of macrostructures and microstructures is important for engineering functional equivalents. ${ }^{\text {E9 }}$ The aortic valve is integrated in the aortic root, forming the structural and dynamic continuity between the left ventricle and ascending aorta. It is composed of the leaflets, the crown-shaped annulus, intervalvular trigones, sinuses of Valsalva, commissures, and the sinotubular junction. All components are in close relationship and cross-talk among each other, the environment, and the whole body during dynamic, cyclic function, ${ }^{4}$ warranting undisturbed unidirectional flow. None of these components stands alone. Novel visualization techniques have revealed the aortic valve leaflets to have a highly complex multilayer mesostructure, providing anisotropic mechanical behavior that differs distinctly from the currently known three-layer morphology. ${ }^{5}$ Endoscopic and microscopic evaluation of the pressureloaded porcine root has shown strong collagen fibers with smaller connecting fibers embedded in hammock-shaped, thin membranes in between (Figure 2), which is a perfect blueprint for suspension bridges. Furthermore, the crimped design of fibers allows stress compensation. Nerve fibers, a complex pattern of extracellular matrix components, and different interstitial and endothelial cellular phenotypes have been identified. They control the transformation of structural, secretory, mitogenic, contractile, and remodeling shear stress stimuli ${ }^{\mathrm{E} 10-\mathrm{E} 15}$ (Figure 3). 
These are only some of already known characteristics of the seemingly simple aortic valve, foreshadowing the incredible variability and complexity of this small organ in particular and of nature in general. Once we are aware of this complexity, it becomes clear why it is so difficult to recapitulate biologic processes by tissue engineering, why there are so many scientific approaches, and why it takes so much time. After two decades of research in this field at a cost of roughly $\$ 4.5$ billion, remarkable scientific results have indeed been achieved ${ }^{6}$; however, fewer than 10 tissueengineered products have made it to the clinical setting. ${ }^{\text {E16 }}$ Altogether, tissue engineering a copy of a patient's specific native valve hardly seems possible at present. But on the way to this ultimate goal, knowledge has already increased and will continue to increase, aiding the production of more biomimetic, improved valve substitutes for clinical use.

In this issue, Hayashida and colleagues ${ }^{7}$ present their respectable results on development of an in vivo tissueengineered autologous heart valve (biovalve) and their preparation of a prototype. A special mold consisting of a silicone rod and a crown-shaped tubular polyurethane scaffold was implanted subcutaneously in rabbits, inducing the formation of a semilunar valve construct. The authors revived an old concept of tissue engineering for vascular grafts ${ }^{\mathrm{E} 17}$ unfortunately prone to several complications, such as early and late thrombosis as well as aneurysm formation. ${ }^{8}$

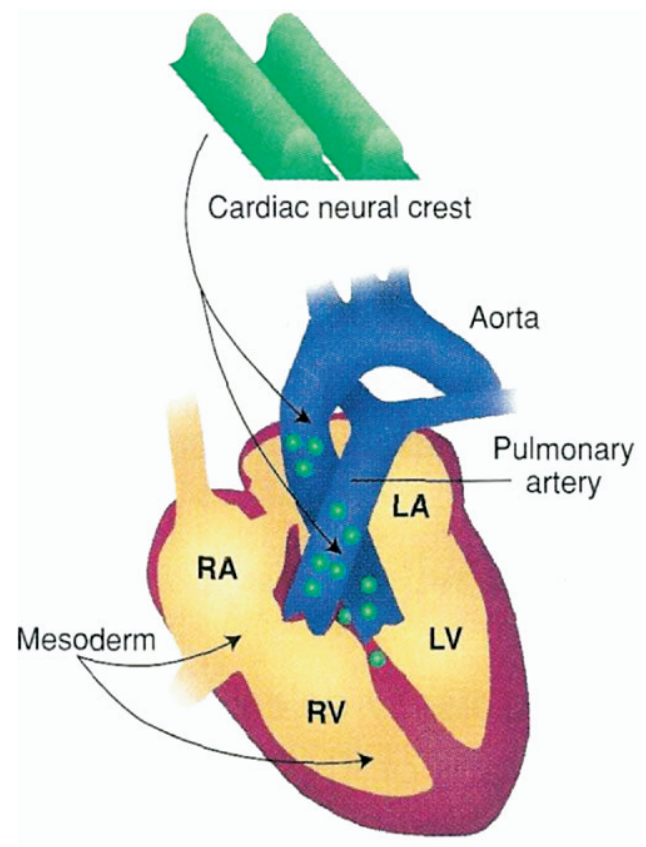

Figure 1. Neural crest cells migrate to left ventricular outflow tract, contributing to development of semilunar valves. $L A$, Left atrium; $R A$, right atrium; $L V$, left ventricle; $R V$, right ventricle. From Hagmann M. A gene that scrambles your heart. Science. 1999;283: 1091-3. Reprinted with permission of Nature Publishing Group.

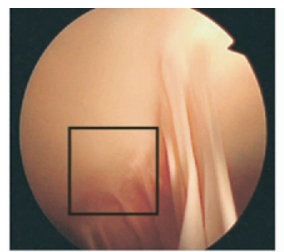

A

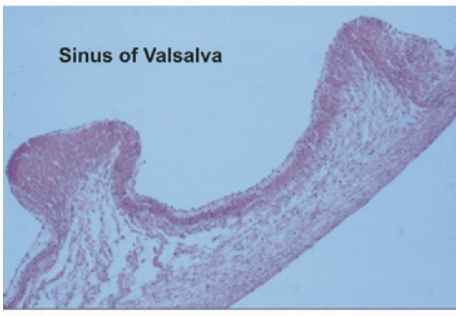

D

B
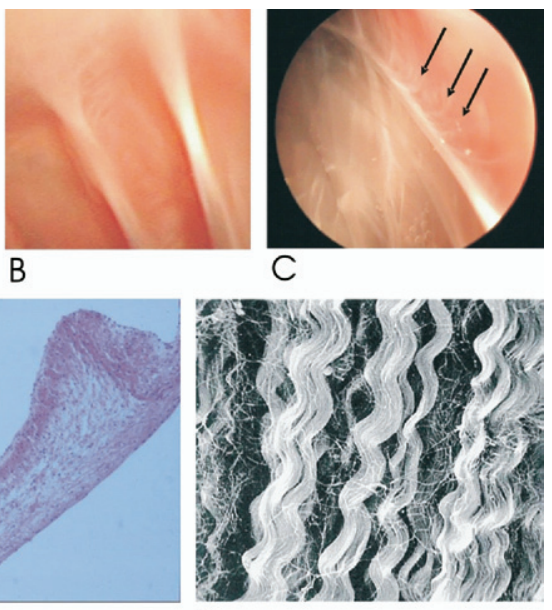

$\mathrm{E}$

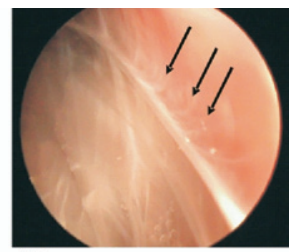

C
Figure 2. A, Endoscopic view into sinus of Valsalva of pressurized porcine aortic root. B, Inset of A, near annulus, strong collagen fibers bear thin, hammock-shaped membranes. C, Smaller collagen fibers are embedded in these membranes (arrows). D, This structural arrangement is shown histologically after fixation under load; red color indicates collagen. (Van Gieson staining courtesy W. Kühnel, Institute of Anatomy, University of Luebeck, Luebeck, Germany.) E, Collagen fibers possess wavy, crimped configuration (Fastenrath $\mathrm{S}$. Texture of collagenous fibers of the aortic/pulmonic valve [thesis]. Kiel, Germany: Univ. of Kiel; 1995.). Reprinted with permission of Sven Fastenrath.

Although this technique may have several advantages in providing an autologous construct, conceptual questions remain open. There were no hemodynamic forces to program structural stimuli, so what were the type and arrangement of collagen fibers, the mesostructure, and the whole

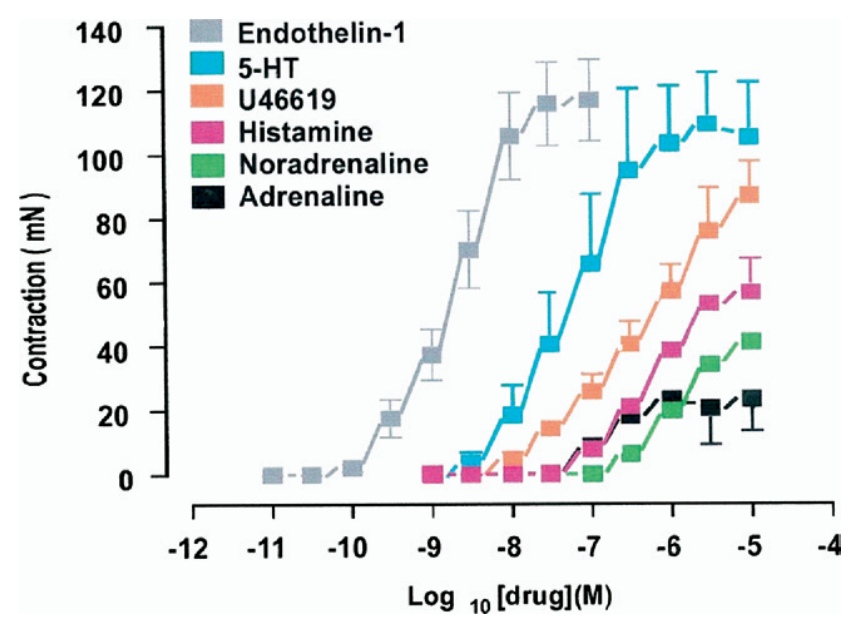

Figure 3. Receptor-mediated contraction of aortic valve leaflets. 5-HT, 5-Hydroxy-L-tryptophan. From Chester AH, Misfeld M, Yacoub MH. Receptor-mediated contraction of aortic valve leaflets. $J$ Heart Valve Dis. 2000;9:250-5. Reprinted with permission from The Journal of Heart Valve Disease. 
spectrum of extracellular matrix components? Immunoreactivity was not found for vimentin, contrary to normal aortic valves. ${ }^{\text {E12 }}$ Furthermore, how do the cells of this construct change their phenotype after coming into contact with pressure and blood? ${ }^{\mathrm{E} 18}$ Finally, what is the durability of the biovalve in circulation? Will thrombotic and aneurysmal complications occur even though the construct looks quite and promising? The underlying mechanism of this kind of valve formation is probably more a foreign-body reaction trying to encapsulate the artificial material rather than a true developmental process. At any rate, the concept of in vivo autologous tissue engineering with the patient as an autologous "bioreactor" is undoubtedly appealing. Other approaches will follow, with more perfect molds or with a hybrid technique that uses 4D biodegradable or nonbiodegradable artificial, xenologous, or autologous scaffolds in an environment simulating hemodynamic forces.

Newly promising principles of regenerative medicine, including tissue engineering and stem cell biology, are entering the field. ${ }^{\mathrm{E} 19}$ The less differentiated the stem cells, the greater is their potential plasticity to develop into different cells. To prevent uncontrolled, teratogenic differentiation, however, they need strategies of control, the right stimuli for structure, function, and time; something like a plan. Furthermore, engineering technology develops rapidly and may contribute to tissue engineering or regenerative medicine by providing, for example, biomimetic, anisotropic, microscale, 3-dimensional, woven composite scaffolds, ${ }^{\text {E20 }}$ ready to take over full load immediately, or even more sophisticated nanomembranes of organic-inorganic interpenetrating networks. ${ }^{\text {E21 }}$ Recently, an artificial polyprotein with nanomechanical properties comparable to those of naturally evolved elastomeric proteins was produced by using single-molecule atomic force microscopy techniques. ${ }^{\text {E22 }}$ In addition, interspecies comparison of evolution might add new and interesting knowledge. For example, the codfish has two semilunar valves in series in the conus arteriosus (Figure 4). Why? For depulsation? For stress reduction?

Clearly, more basic research, stimulated by workshops like the recent National Institutes of Health workshop on tissue engineering in 2005, is mandatory to increase knowledge in understanding biologic factors, especially the control of cell behavior, tissue function, aging, reparation, regeneration, vascularization, remodeling, and decellularization and recellularization of scaffolds. On the other hand, engineering factors including scaffold technology, nanotechnology, protein design, computational and communicating technology, and tools for translation to tissue engineering will be developed. Clinical trials on this field should be

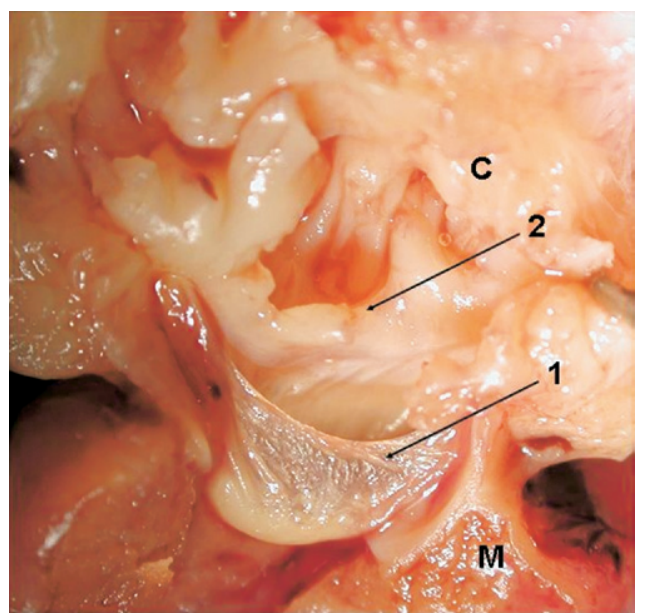

Figure 4. In codfish hearts, there are two semilunar valves and sinuses of Valsalva located in series in conus arteriosus (C). 1, First semilunar valve; 2 , second semilunar valve; $M$, ventricular muscle.

carefully, prudently conducted and audit controlled. Successes - but also failures - should be published with a spirit of cooperation in a "flattening" world, ${ }^{\mathrm{E} 23}$ and hopes should be raised but not overstated.

As I write these lines, Michelangelo's depiction of the creation of Adam by God, depicted with a drapery looking something like the human brain, enters my mind. Let's use our creativity and consciousness and try to get what we can. The bar is set very high.

\section{References}

1. Hove JR, Koster RW, Forouhar AS, Acevedo-Bolton G, Fraser SE, Gharib M. Intracardiac fluid forces are an essential epigenetic factor for embryonic cardiogenesis. Nature. 2003;421:172-7.

2. Hagmann M. A gene that scrambles your heart. Science. 1999;283: 1091-3.

3. Rabkin-Aikawa E, Farber M, Aikawa M, Schoen FJ. Dynamic and reversible changes of interstitial cell phenotype during remodeling of cardiac valves. J Heart Valve Dis. 2004;13:841-7.

4. Yacoub MH, Kilner PJ, Birks EJ, Misfeld M. The aortic outflow and root: a tale of dynamism and crosstalk. Ann Thorac Surg. 1999;68 Suppl $1: 37-43$

5. Doehring TC, Kahelin M, Vesely I. Mesostructures of the aortic valve. J Heart Valve Dis. 2005;14:679-86.

6. Sutherland FW, Perry TE, Yu Y, Sherwood MC, Rabkin E, Masuda Y, et al. From stem cells to viable autologous semilunar heart valve. Circulation. 2005;111:2783-91

7. Hayashida K, Kanda K, Yaku H, Ando J, Nakayama Y. Development of an in vivo tissue-engineered autologous heart valve (the Biovalve) J Thorac Cardiovasc Surg. 2007;134:152-9.

8. Hallin RW, Sweetman WR. The Sparks' mandril graft. A seven year follow-up of mandril grafts placed by Charles H. Sparks and his associates. Am J Surg. 1976;132:221-3. 
E1. McIntire LV, Greisler HP, Griffith L, Johnson PC, Mooney DJ, Mrksich M, et al. WTEC panel report on tissue engineering research. Baltimore: Loyola College; 2002.

E2. Mjaatvedt CH, Yamamura H, Wessels A, Ramsdell A, Turner D, Markwald RR. Normal and abnormal morphogenesis: mechanism of segmentation, septation, and remodeling of the tubular heart: endocardial cushion fate and cardiac looping. In: Harvey RP, Rosenthal N, editors. Heart development. San Diego: Academic Press; 1999. p. 159-74.

E3. Schroeder JA, Jackson LF, Lee DC, Camenisch TD. Form and function of developing heart valves: coordination by extracellular matrix and growth factor signaling. J Mol Med. 2003;81:392-403.

E4. Jiang X, Rowitch DH, Soriano P, McMahon AP, Sucov HM. Fate of the mammalian cardiac neural crest. Development. 2001;27:1607-16.

E5. Nakamura T, Colbert MC, Robbins J. Neural crest cells retain multipotential characteristics in the developing valves and label the cardiac conduction system. Circ Res. 2006;98:1547-54.

E6. Mohamed SA, Hanke T, Schlueter C, Bullerdieck I, Sievers HH. Ubiquitin fusion degradation 1-like gene dysregulation in bicuspid aortic valve. J Thorac Cardiovasc Surg. 2005;130:1531-6.

E7. Kirby ML, Waldo KL. Role of neural crest in congenital heart disease. Circulation. 1990;82:332-40.

E8. Boyer AS, Finch WT, Runyan RB. Trichloroethylene inhibits development of embryonic heart valve precursors in vitro. Toxicol Sci. 2000;53:109-17.

E9. Cowin SC. How does nature build a tissue?. In: Guilak F, Butler DL, Goldstein SA, Mooney DJ, editors. Functional tissue engineering. New York: Springer; 2003. p: 3-16.

E10. Marron K, Yacoub MH, Polak JM, Sheppard MN, Fagan D, Whitehead BF, et al. Innervation of human atrioventricular and arterial valves. Circulation. 1996;94:368-75.

E11. Latif N, Sarathchandra P, Taylor PM, Antoniw J, Yacoub MH. Localization and pattern of expression of extracellular matrix components in human heart valves. J Heart Valve Dis. 2005;14:218-27.
E12. Della Rocca F, Sartore S, Guidolin D, Bertiplaglia B, Gerosa G, Casarotto D, et al. Cell composition of the human pulmonary valve: a comparative study with the aortic valve-the VESALIO Project. Vitalitate Exornatum Succedaneum Aorticum labore Ingegnoso Obtinebitur. Ann Thorac Surg. 2000;70:1594-600.

E13. Taylor PM, Allen SP, Dreger SA, Yacoub MH. Human cardiac valve interstitial cells in collagen sponge: a biological three-dimensional matrix for tissue engineering. J Heart Valve Dis. 2002;11:298-306.

E14. Hafizi S, Taylor PM, Chester AH, Allen SP, Yacoub MH. Mitogenic and secretory responses of human valve interstitial cells to vasoactive agents. J Heart Valve Dis. 2000;9:454-8.

E15. Li YSJ, Haga JH, Chien S. Molecular basis of the effects of shear stress on vascular endothelial cells. J Biomech. 2005;38:1949-71.

E16. Lysaght MJ, Hazlehurst AL. Tissue engineering: the end of the beginning. Tissue Eng. 2004;10:309-20

E17. Sparks CH. Silicone mandril method of femoropopliteal artery bypass. Clinical experience and surgical technics. Am J Surg. 1972; 124:244-9.

E18. Badylak SF, Grompe M, Caplan AI, Greisler HP, Guldberg RE, Taylor DA. In vivo remodeling: breakout session summary. Ann NY Acad Sci. 2002;961:319-22.

E19. Angelini P, Markwald RR. Stem cell treatment of the heart. Tex Heart Inst J. 2005;32:479-88.

E20. Moutos FT, Freed LE, Guilak F. A biomimetic three-dimensional woven composite scaffold for functional tissue engineering of cartilage. Nat Mater. 2007;6:162-7.

E21. Vendamme R, Onoue SY, Nakao A, Kunitake T. Robust freestanding nanomembranes of organic/inorganic interpenetrating networks. Nat Mater. 2006;5:494-501.

E22. Cao Y, Li H. Polyprotein of GB1 is an ideal artificial elastomeric protein. Nat Mater. 2007;6:109-14.

E23. Levitski S. Navigating the new "flat world" of cardiothoracic surgery. Ann Thorac Surg. 2007;83:361-9. 